\title{
MANAJEMEN PELATIHAN COORPORATE SOCIAL RESPONSIBILITY (CSR) DI COORPORATE FORUM FOR COMUNITY DEVELOPMENT (CFCD) JAKARTA
}

\author{
Nur Lis Aviani, Siti Zulaikha, Wahyu Sri Ambar Arum \\ nurlisa_gitarra@yahoo.com
}

\begin{abstract}
This research was conducted at the Division of Training Coorporate Forum For Comunity Development, Jakarta, which aim to identify CSR training management process. This research was conducted on April 2015 to January 2016. This research used qualitative approach with descriptive methode. Data was collected through interview, observation and documentation study. Data sources was gained from Managing Director, Training Manager, Managing Secretary, and several supported informants such as Training Manager Assistant, Training Instructor and CSR Training Participant.Planning of CSR training was conducted by analyzing training needs, arrange curriculum, materials, teaching materials, schedule and organizing recruitment of participants and instructor. While the implementation of training activities carried out through two stages including basic training dan advance training. Evaluation was held by asessing the organizers, training program, materials, instructor, facilities and training participants through four ways to measurereaction,learning, behavior and result.Training Division should be more active and cooperative while planning a training schedule, and give socialization and publication about the importance of CSR training baed on ISO 26000 as much as possibe, altering group discussion formation in order to give encouragement for passive participants to become more active, Reminding participants anymore about the importance of filling evaluation form, establishing cooperation with government and stakeholder to achieve prosperity of civil society by conducting CSR program based on ISO 26000
\end{abstract}

Keywords : Training Management,Coorporate Social Responsibility

\section{Pendahuluan}

Corporate Social Responsibility (CSR) adalah suatu tindakan yang dilakukan oleh perusahaan sebagai bentuk tanggung jawab terhadap lingkungan sosial di sekitar tempat perusahaan tersebut didirikan.Bentuk tanggung jawab tersebut beragam, mulai dari kegiatan peningkatan kesejahteraan masyarakat dan perbaikan lingkungan, pemberian beasiswa bagi anak tidak mampu, sumbangan dana bagi pembangunan prasarana pendidikan di daerah tempat perusahaan tersebut berada. Keberadaan CSR timbul karena kesadaran perusahaan akan kekokohan perusahaan jangka panjang lebih penting daripada sekedar mengejar keuntungan semata. Sumber daya manusia merupakan aset berharga dalam menggerakkan roda organisasi. Sumber daya manusia terdiri dari sekumpulan orang orang yang memiliki kompetensi tertentu yang bekerja sama dalam meraih tujuan organisasi. Maka dari itu, diperlukan upaya pengembangan sumber daya manusia untuk menambah kualitas dan integritas sehingga organisasi dapat bersaing di masa yang akan datang. Pelaksana CSR merupakan bagian 
dari sumber daya manusia dalam organisasi yang perlu dikembangkan melalui kegiatan pendidikan dan pelatihan. Hasil Program Penilaian Peringkat Perusahaan (PROPER) Tahun 2004-2005 Kementerian Negara Lingkungan Hidup menunjukkan bahwa dari 466 perusahaan dipantau ada 72 perusahaan mendapat rapor hitam, 150 merah, 221 biru, 23 hijau, dan tidak ada yang berperingkat emas. Dengan begitu banyaknya perusahaan yang mendapat rapor hitam dan merah, menunjukkan bahwa mereka tidak menerapkan tanggung jawab lingkungan. Disamping itu dalam prakteknya tidak semua perusahaan menerapkan CSR.Bagi kebanyakan perusahaan, CSR dianggap sebagai parasit yang dapat membebani biaya "capital maintenance". Kalaupun ada perusahaan yang melakukan CSR, itupun dilakukan hanya demi menjaga reputasi dan nama baik perusahaan. Jarang ditemui program CSR yang memberikan kontribusi langsung kepada masyarakat secara total.Di tengah kepedulian akan CSR yang masih kurang, Pemerintah membuat regulasi berupa Undang-Undang yang mengatur tentang pemenuhan tanggung jawab sosial perusahaan.UU No. 40 Tahun 2007 tentang Perseroan Terbatas (UU PT) yang menyebutkan bahwa " Setiap perseroan yang menjalankan kegiatan usahanya di bidang dan/atau berkaitan dengan sumber daya alam wajib melaksanakan tanggung jawab sosial dan lingkungan. Jika tidak dilakukan, maka perseroan tersebut akan terkena sanksi sesuai dengan ketentuan perundang-undangan. Selama 15 tahun terakhir, tidak banyak lembaga pelatihan CSR yang hadir di Indonesia. Dulu, CSR masih dipandang sebelah mata dan tidak mempunyai efek yang signifikan terhadap perusahaan. Tetapi setelah muncul berbagai undang-undang yang mengatur tanggung jawab sosial perusahaan, setiap perusahaan yang melakukan kegiatan usaha wajib memenuhi tangung jawab sosial terhadap masyarakat di lingkungan perusahaan melalui kegiatan CSR.Kegiatan CSR kini bukan lagi bersifat sukarela melainkan bersiat mandatori. Sekarang ini mulai banyak bermunculan diklat CSR misalnya Management Center For Coorporate Sustainability (MCCS), Kirana Adhirajasa, Coorporate Forum Training (CFT) dan masih banyak lagi. Hal ini memotivasi CFCD Jakarta untuk menjadi penyelenggara diklat CSR yang unggul dan mampu berkompetisi dengan penyelenggara diklat CSR yang lain. CFCD sendiri sudah berdiri selama lebih dari 12 tahun. CFCD Jakarta semakin berkembang.CFCD sendiri baru saja menyelesaikan pembangunan gedung tambahan. Animo peserta yang ingin mengikuti pendidikan dan pelatihan CFCD Jakarta semakin bertambah setiap tahunnya. Maka dari itu, CFCD Jakarta memiliki kesadaran penuh untuk selalu melakukan peningkatan dalam pengelolaan kegiatan diklat. Manajerial yang baik akan menghasilkan output yang berkompeten pula. Untuk itu, peneliti perlu mengkaji bagaimana " Manajemen Pendidikan dan Pelatihan CSR di CFCD, Jakarta.

\section{Kajian Teori}

Menurut Harudjito (2001), Istilah manajemen berasal dari kata kerja to manage yang berarti control. Dalam bahasa Indonesia dapat diartikan: mengendalikan, menangani atau mengelola. Pendapat George R. (2001) pengertian manajemen sebagai berikut: "Manajemen adalah suatu proses yang berbeda terdiri dari planning, organizing, actuating dan controlling yang dilakukan untuk mencapai tujuan yang ditentukan dengan menggunakan manusia dan sumber daya lainnya." Menurut Kamus Besar Bahasa Indonesia, pelatihan adalah proses, cara belajar dan membiasakan diri agar mampu/dapat melakukan sesuatu. Menurut Mangkupawira (2014:13), pelatihan adalah "sebuah proses mengajarkan pengetahuan 
dan keahlian tertentu serta sikap agar karyawan semakin terampil dan mampu melaksanakan tanggung jawabnya dengan semakin baik sesuai standar".

Pelatihan menurut Jill Brokes (1995:62) memiliki arti "proses terencana untuk mengubah sikap, pengetahuan, keterampilan dan perilaku melalui pengalaman pembelajaran guna mencapai kinerja yang efektif dari suatu kegiatan atau berbagai kegiatan." Sadili (2005:3) mengungkapakan bahwa "pelatihan bersifat spesifik, praktis dan segera."

Menurut Ardie (2015) manajemen pelatihan yang sistematis dan terencana meliputi tahap perencanaan, pelaksanaan, pengawasan dan evaluasi. Menurut Basri dan Rusdiana (2005:28) Kegiatan pelatihan harus dikelola/dimanajemen dengan baik mulai dari kegiatan identifikasi kebutuhan, perancangan program, pengorganisasian, pelaksanaan dan evaluasi pelatihan secara sistematis.

Menurut Tim Pengembang Ilmu Pendidikan FIP-UPI, manajemen pelatihan mencakup perencanaan, pengorganisasian, penggerakan, pembinaan, penilaian, pengembangan sistem dan program pelatihan. Menurut Karen Lawson yang dikutip oleh Basri dan Rusdiana, strategi pelatihan bertujuan untuk menambah pengetahuan, meningkatkan keterampilan dan menumbuhkan sikap (perilaku).

Menurut The World Bussiness Council For Sustainable Development (WBCSD) tahun 1999 sebagai berikut: "Continuing comitment of bussiness to behave ethically and contribute to economic development while improving the quality of life of the workforce and their families as well as of the local comunity and society at large". Menurut Rudito dan Famiola (2013), tanggung jawab sosial perusahaan adalah sebuah kebutuhan bagi korporat untuk dapat berinteraksi dengan komunitas lokal sebagai bentuk masyarakat keseluruhan. Rosmasita mendifinisikan Coorporate Social Responsibility sebagai: "Usaha perusahaan untuk menyeimbangkan komitmenkomitmennya terhadap kelompok-kelompok dan individual-individual dalam lingkungan perusahaan tersebut, termasuk di dalamnya adalah pelanggan perusahaan lain, para karyawan dan investor"

\section{Metode Penelitian}

Pada dasarnya, tujuan dari studi ini yaitu untuk mendeskripsikan mengenai manajemen pendidikan dan pelatihan CSR di Cooporate Forum For ComunityDevelompent (CFCD),Jakarta. Penelitian ini menggunakan analisis deskripstif dengan metod kualitatif sebagai landasan utama dalam penelitian.Dengan pendekatan kualitatif ini diharapkan mampu menguraikan secara mendetail mengenai proses perencanaan, pelaksanaan dan evaluasi pelatihan CSR di CFCD. Dalam penelitian ini, peneliti melihat semua proses kegiatan manajemen pelatihan CSR di CFCD. Teknik pengumpulan data dilakukan melalui pengamatan atau observasi, peran serta, hasil wawancara, studi dokumenatsi dan hasil pemotretan atau fotografi. Data yang dikumpulkan peneliti mengenai proses perencanaan, pelaksanaan dan evaluasi pelatihan CSR di CFCD. Teknik pemilihan informan dilakukan dengan teknik snowball sampling. Teknik ini dipilih karena peneliti meminta rujukan kepada informan yang dimintai informasi pertama kali untuk menyebutkan informan lain yang bisa dijadikan sebagai sumber informasi yang sesuai dengan objek penelitian. Hal tersebut menunjukkan bahwa informan pertama merupakan informan kunci atau key informan yang dapat memberikan berbagai data 
penting yang dibutuhkan pleh peneliti dan informan lainnya adalah sebagai informan pendukung. Sebagaimana lazimnya peroleh data dalam penelitian kualitatif, data dapat diperoleh dari semua pihak yang bersangkutan baik melalui wawancara, observasi, partisipasi dan dokumentasi.Perolehan data tersebut dalam catatan lapangan yang menggambarkan setting dan hasil wawancara yang memuat informasi penting yang dapat menjawab pertanyaan penelitian. Data yang didapat dari tahap pra lapangan dan pekerjaan lapangan selanjutnya dianalisis dengan menggunakan teknik analisis data untuk penelitian kualitatif, termasuk didalamnya mengklasifikasi data dan mereduksi data.Instrumen penelitian ini dibuat dan dilakukan oleh peneliti dengan teknik pengumpulan data berupa wawancara, observasi dan studi dokumentasi. Analisis data dilakukan oleh peneliti selama proses penelitian. Artinya, pelaksanaan analisis data sudah mulai dilakukan sejak pengumpulan data dilakukan dan dikerjakan secara intensif sesduah meninggalkan lapangan.Adapun langkah-langkah teknik analisis data menurut Sugiyono (2009) yaitu redukdi data, penyajian data dan pengambilan kesimpulan.

\section{Hasil dan Pembahasan}

Tahapan perencanaan pelatihan CSR di CFDC diawali dengan melakukan analisis kebutuhan. Hal ini sejalan dengan teori yang dikemukakan oleh Ma'arif dan Kartika bahwa perencanaan pelatihan yang efektif diwali dengan analisis kebutuhan. Dalam melakukan perencanaan pelatihan, direktur pelaksana terlebih dahulu melakukan analisis kebutuhan terkait materi pelatihan. Analisis kebutuhan pelatihan dilakukan dengan cara melihat apa kompetensi yang dibutuhkan untuk menjadi pelaksana CSR yang berdedikasi tinggi. Untuk menghasilkan alumni pelatihan yang mengerti tugas pokok dan fungsinya sertamemiliki kompetensi yang tinggi di bidang manajemen program CSR. Ada tigaaspek yang menjadi bahan pertimbangandalam menyusun materi yaitu: PKS (Pengetahuan, Keterampilan, Sikap. Direktur pelaksana juga melakukan perencanaan sumberdaya, termasuk seluruh infrastruktur yang menunjang pelaksanaan pelatihan, menyusun penganggaran serta mengatur kebijakan strategis pelatihan.

Pada tahap selanjutnya, sekretaris pelaksana bertugas menidentifikasi kebutuhan materi pelatihan, menyusun kurikulum, silabus, menerjemahkan kurikulum ke dalam bentuk modul atau bahan ajar serta melakukan pengembangan kurikulum. Sedangkan manajer pelatihan bertugas menyusun modul pelatihan, menetapkan instruktur dan menyusun jadwal kegiatan pelatihan. Kemudian asisten manajer training membantu menyiapkan lokasi pelatihan, menyiapkan sarana dan prasarana serta fasilitas pelatihan dan serta melakukan rekruitmen peserta. Tahapan perencanaan yang dilakukan oleh CFCD telah sesuai dengan tahapan perencanaan yang dikemukakan oleh Mujiman (2007) sebagai berikut 1) Menetapkan bahan ajar pelatihan 2)Menetapkan alat bantu pelatihan dalam menyusun materi pelatihan 4) Menetapkan tempat dan waktu pelatihan 5)Menyusun rencana kegiatan dan jadwal pelatihan.

CFCD melakukan perencanaan pelatihan dengan tepat dan efektif untuk memudahkan dalam mencapai tujuan pelatihan sehingga peserta pelatihan mendapatkan bekal kemampuan dan kompetensi yang sesuai dengan kebutuhannya. Hali ini sejalan dengan teori Ma'arif dan Kartika (2014) yaitu perencanaan pelatihan yang efektif diawali dengan analisis kebutuhan.

Metode pengajaran merupakan hal yang utama dalam program pelatihan.Pemilihan 
metode yang tepat berpengaruh terhadap ketercapaian kompetensi sesuai dengan kurikulum yang telah disusun sebelumnya. Tujuan kurikulum dan metode pengajaran adalah dua hal yang saling berkaitan.Dalam pelaksanaan pelatihan, CFCD telah memilih metode pelatihan dan media komunikasi yang tepat demi tercapainya tujuan kurikulum. Metode andragogi yang diterapkan dalam pelatihan ini mampu meningkatkan keaktifan para peserta pelatihan di dalam kelas. Hal ini senada dengan teori yang digagas oleh Marzuki (2009) bahwa metode pembelajaran andragogi merupakan proses bantuan terhadap orang dewasa agar dapat belajar secara maksimal

Dalam hal teori, metode pembelajaran andragogi berpusat pada masalah belajar, menuntut dan mendorong peserta latihan untuk aktif, mendorong peserta pelatihan untuk mengemukakan pengalamannya, menimbulkan kerja sama antara intruktur dengan peserta dan antara sesama peserta pelatihan. Dalam hal praktik, metode ini meningkatkan produktivitas, memperbaiki kualitas kerja, mengembangkan keterampilan baru dan membantu menggunakan alat-alat dengan cara yang tepat serta meningkatkan keterampilan.

Metode pembelajaran yang diterapkan dalam pelatihan CSR di CFCD sesuai dengan teknik atau metode yang digunakan untuk membantu proses belajar orang dewasa. Hal ini senada dengan teori yang diungkapkan oleh Isnaini bahwa:Ada beberapa teknik atau metode yang dapat digunakan untuk membantu proses belajar orang dewasa antara lain: 1) Presentasi. Tehnik ini meliputi: ceramah, debat, dialog, wawancara, demonstrasi, film, slide, pameran. 2) Teknik Partisipasi peserta. Teknik ini meliputi: tanya jawab, bermain peran, kelompok panel dan panel yang diperluas. 3) Teknik Diskusi,
Teknik ini terdiri atas diskusi terpimpin, diskusi yang bersumber dari buku, diskusi pemecahan masalah dan diskusi kasus. Metode presentasi digunakan oleh instruktur CFCD untuk menampilan tayangan maupun video yang berkaitan dengan dunia CSR. Teknik partisipasi peserta digunakan dalam sesi sharing dan dialog. Peserta diberi kesempatan berdialog dan melakukan tanya jawab dengan CSR Best Practice yaitu perusahaan yang berhasil menjalankan program CSR dengan berdasarkan ISO 26000 SR dan telah mendapatkan CSR Award (penghargaan). Dalam sesi ini, dihadirkan narasumber dari berbagai kalangan atau stakeholder yang memiliki kompetensi sebagai Tim panel/penilai dan berfungsi sebagai pengamat.

Teknik diskusi digunakan dalam pelatihan ini mengasah keterampilan berbicara. Diskusi yang dilaksanakan dalam pelatihan ini berjalan terarah karena narasumber dan panelis yang dihadirkan adalah orang-orang yang profesional dan mengerti seluk beluk dunia CSR. Studi kasus yang dimunculkan sebagai bahan diskusi bertujuan untuk mengasah ketajaman analisis dan menumakan solusi atas ketika suatu masalah atau kasus yang digulirkan. Contoh kasus yang dihadirkan relevan dan dekat dengan latar belakang perusahaan tempat peserta bekerja.

Evaluasi pelatihan di CFCD meliputi berbagai aspek yaitu : peserta, instruktur, fasilitas dan kurikulum. Model evaluasi yang diterapkan oleh CFCD adalah model evaluasi Kirkpatrick, yang terdiri dari empat tahapan yaitu reaction, learning, behaviour dan result. Hal ini senada dengan teori yang dicetuskan oleh Kickpatrick yaitu: "The four levels technique for evaluating training programs" yang terdiri dari reaction, learning, behavior dan results. Pada tahap satu, peserta menilai instruktur, materi, 
sarana dan prasarana, program pelatihan dan penyelenggara melalui pengisian angket yang dibuat oleh penyelenggara.

Pada tahap satu yaitu reaction, peserta menilai instruktur, materi, sarana dan prasarana, program pelatihan dan penyelenggara melalui pengisian angket yang dibuat oleh penyelenggara. Melalui cara ini, penyelenggara dapat mengetahui reaksi dan kepuasan peserta terhadap kegiatan pelatihan yang telah berjalan. Setelah diisi oleh peserta, hasil data mentah tersebut diubah menjadi data kuantitatif. Kemudian dilakukan analisis untuk mengetahui tingkat kepuasan peserta training. Setiap evaluasi pelatihan yang diselenggarakan CFCD, selalu memperoleh hasil yang memuaskan karena setiap instrumen yang diisi dalam angket evaluasi selalu mendapatkan score diatas 300. Artinya, penyelenggaraan pelatihan di CFCD telah berjalan dengan baik sesuai dengan harapan peserta training. Pada tahap kedua yaitu learning, penyelenggara dapat melihat kemajuan hasil belajar peserta melalui pre-test dan post-test yang diberikan oleh instruktur. Soal-soal yang diberikan berkaitan dengan materi yang telah diajarkan mengenai manajemen program CSR berbasis ISO 26000. Setiap butir soal esai diberi nilai dan diakumulasi. Dari hasil tersebut, maka diketahui sejauh mana tingkat perubahan pengatahuan, keterampilan dan sikap yang ada pada diri peserta setelah mengikuti pelatihan.

Sedangkan pada tahap ketiga, perubahan perilaku peserta dapat dilihat ketika CFCD mengadakan Pertemuan Rutin (Round Table Discussion)secara bergilir/berkala dalam mempertukarkan pengalaman penyelenggaraan (Coorporate Social Responsibility) perusahaan. CFCD mengadakan pertemuan ini untuk memantau kembali bagaimana perkembangan peserta setelah mengikuti pelatihan. Dari Round
Table Discussion tersebut juga akan diketahui apakah peserta telah berhasil melaksanakan progarm CSR berbasis ISO 26000 serta melaksanakan program pengembangan masyarakat dengan tepat sesuai dengan ilmu dan keterampilan yang mereka dapat dari pelatihan CSR di CFCD. Pada sesi round table discussion, didapat informasi mengenai beberapa peserta yang telah naik jabatan karena kinerjanya sebagai CDO semakin baik.

Pada tahap terakhir yaitu results, hasil akhir pelatihan dapat dilihat dari keberhasilan CDO perusahaan yang telah berhasil meraih penghargaan ICA. CFCD memberikan penghargaan Indonesian CSR Awards (ICA). Penghargaan ICA ditujukan untuk perusahaan yang telah berhasil menjalankan program CSR yang berlandaskan ISO 26000. Ada sekitar 37 Perusahaan anggota CFCD yang berhasil meraih penghargaan ICA. Selain penghargaan dari CFCD, ada banyak peserta alumi pelatihan CFCD yang telah berhasil mendapatkan Gold Achievment atau medali emas maupun medali perak dari Pemerintah atas keberhasilannya melaksanakan program CSR berbasis ISO 26000.

\section{Kesimpulan}

Berdasarkan hasil analisis data yang diperoleh di lapangan, maka penelitian ini dapat dijabarkan sebagi berikut:

1. Tahapan perencanaan yang dilakukan oleh Direktur Pelaksana diawali dengan melakukan analisis kebutuhan pelatihan dengan cara melihat apa kompetensi yang dibutuhkan untuk menjadi pelaksana CSR yang berdedikasi tinggi. Karena CFCD tidak hanya memberi pelatihan tetapi juga mengarahkan para CDOperusahaan agar mengerti tugas 
pokok dan fungsinya sertamemiliki kompetensi yang tinggi di bidang manajemen program Ada tigaaspek yang menjadi bahan pertimbangandalam menyusun materi yaitu: PKS (Pengetahuan, Ketrampilan , Sikap. Direktur pelaksana juga melakukan perencanaan sumberdaya, termasuk seluruh infrastruktur yang menunjang pelaksanaan pelatihan, menyusun penganggaran serta mengatur kebijakan strategis pelatihan Perencanaan pelatihan yang efektif diawali dengan analisis kebutuha. CFCDtelah melakukan perencanaan pelatihan dengan tepat dan efektif untuk memudahkan dalam mencapai tujuan pelatihan sehingga peserta pelatihan mendapatkan bekal kemampuan dan kompetensi yang sesuai dengan kebutuhannya.

2. Pelatihan CSR di CFCD menggunakan metode partisipatif dan andragogi artinya partisipasi aktif peserta didik memiliki peranan penting dalam kesuksesan pembelajaran. Metode pelatihan yang digunakan adalah metode ceramah, workshop, diskusi dan studi banding. Metode presentasi digunakan oleh instruktur CFCD untuk menampilan tayangan maupun video yang berkaitan dengan dunia CSR. Teknik partisipasi peserta digunakan dalam sesi sharing dan dialog. Peserta diberi kesempatan berdialog dan melakukan tanya jawab dengan CSR Best Practice yaitu perusahaan yang berhasil menjalankan program CSR dengan berdasarkan ISO 26000 SR dan telah mendapatkan CSR Award (penghargaan).Metode andragogi yang diterapkan dalam pelatihan ini mampu meningkatkan keaktifan para peserta pelatihan di dalam kelas.
Peserta bebas menyampaikan pendapat, ide dan gagasan. Maka dari itu, dibutuhkan teknik atau metode pembelajaran yang tepat sesuai dengan kondisi psikologis orang dewasa. Metode pembelajaran yang diterapkan dalam pelatihan CSR di CFCD sesuai dengan teknik atau metode yang digunakan untuk membantu proses belajar orang dewasa

3. Evaluasi pelatihan di CFCD meliputi berbagai aspek yaitu : peserta, instruktur, fasilitas dan kurikulum. Model evaluasi yang diterapkan oleh CFCD adalah model evaluasi Kirkpatrick, yang terdiri dari empat tahapan yaitu reaction, learning, behaviour dan result. Pada tahap satu yaitu reaction, peserta menilai instruktur, materi, sarana dan prasarana, program pelatihan dan penyelenggara melalui pengisian angket yang dibuat oleh penyelenggara. Melalui cara ini, penyelenggara dapat mengetahui reaksi dan kepuasan peserta terhadap kegiatan pelatihan yang telah berjalan. Pada tahap kedua yaitu learning, penyelenggara dapat melihat kemajuan hasil belajar peserta melalui pre-test dan post-test yang diberikan oleh instruktur.

Sedangkan pada tahap ketiga, perubahan perilaku peserta dapat dilihat ketika CFCD mengadakan Pertemuan Rutin (Round Table Discussion)secara bergilir/berkala dalam mempertukarkan pengalaman penyelenggaraan (Coorporate Social Responsibility) perusahaan. CFCD mengadakan pertemuan ini untuk memantau kembali bagaimana perkembangan peserta setelah mengikuti pelatihan.Pada tahap terakhir yaitu results, hasil akhir pelatihan dapat dilihat dari keberhasilan CDO 
perusahaan yang telah berhasil meraih penghargaan ICA. CFCD memberikan penghargaan Indonesian CSR Awards (ICA).

\section{Saran}

Berdasarkan hasil wawancara, implikasi dan kesimpulan, maka peneliti memberikan beberapa saran sebagai berikut :

1. Kepada Divisi Pelatihan CFCD, saran yang dapat diberikan adalah dalam proses perencanaan pelatihan Divisi Pelatihan sulit menetukan jadwal pelatihan yang tepat dan tidak berbenturan dengan jadwal kegiatan calon peserta pelatihan terutama calon peserta yang merupakan anggota CFCD. Maka dari itu, seharusnya Direktur pelaksana dan sejumlah staf yang berwenanng dalam penyusunan jadwal pelatihan harus lebih aktif dalam melakukan negosiasi dengan para CDO sehingga didapatkan kesepakatan waktu. Dalam hal mengatur jadwal, dibutuhkan kejelian dan kehati-hatian agar negosiasi berjalan lebih cepat.Sedangkan dalam hal evaluasi, Bila angket dibagikan, dan peserta tidak mengisi secara penuh, pihak penyelenggara pelatihan perlu memperingatkan kembali kepada peserta ketika sedang mengisi angket, untuk mengisi secara penuh. Panitia memohon kesadaran para peserta dan menjelaskan kembali tentang pentingnya angket evaluasi demi pelaksanaan pelatihan yang semakin baik di kemudian harinya.

2. Kepada Peneliti lain, saran yang didapat bagi peneliti lain adalah hendaknya peneliti hendaknya lebih kreatif dalam mengembangkan kajian penelitian dengan menggunakan metode yang variatif. Peneliti lain juga harus membaca berbagai media informasi untuk menggali wawasan dan informasi yang paling aktual terkait obyek penelitian.

\section{Daftar Pustaka}

Basri, Hasan dan H. A Rusdiana. (2015). Manajemen Pendidikan dan Pelatihan. Bandung: Pustaka Setia.

Brokes, Jill. (1995). Training and

Develompment Competition. London:

KoganPage.

Harudjito, Yayat M. (2001). Dasar-dasar

Manajemen Pendidikan. Jakarta: Gramedia.

ISO 26000 tentang Global Compact, dan Milenium Development Goal (MDG), Guidance Standard on Social Responsibility

Hardhina, Rosmashita. Faktor-faktor yang Mempengaruhi Pengungkapan Sosial dalam Laporan Keuangan Tahunan Perusahaan Bursa Efek Jakarta. Skripsi Univeritas Islam Indonesia

Hasil Program Penilaian Peringkat Perusahaan (PROPER) Tahun 2004-2005

Kementerian Negara Lingkungan Hidup

Marzuki, H. M. (2009). Pendidikan Non

Formal . Bandung: PT. Remaja Rosdakarya.

Rudito, Bambang. Famiola, Melia. (2013). CSR (Coorporate Social Responsibilty).

Bandung: Rekayasa Sains.

Sugiono. (2013). Metode Penelitian

Pendidikan. Bandung: Alfabeta.

Tim Pengembang Ilmu Pendidikan FIP-UPI. (2007). Ilmu \& Aplikasi Pendidikan.

Bandung: Pustaka Grasindo. 
The World Bussiness Council For Sustainable Development (WBCSD) tahun 1999

UU No. 40 Tahun 2007 tentang Perseroan Terbatas (UU PT)

Ardie, Romie. Manajemen Pendidikan dan Pelatihan Bagi Organisasi.diakses pada tanggal 17 Febuari 2015.

http://sembilandewi.blogspot.com/2014/04/ manajemen-pendidikan-dan-pelatihanbagi.html

Isnaini, Muhammad. Andragogi, Suatu Orientasi Baru. diakses pada tanggal 17 Febuari 2015.

http://muhammadisnain.blogspot.com. 